Agus: Konsep Pendidikan....................

\title{
KONSEP PENDIDIKAN LINGKUNGAN HIDUP DALAM PANDANGAN ISLAM
}

\author{
Agus Sulistyo \\ Program Studi Magister Pendidikan Agama Islam, Universitas Ahmad Dahlan, Yogyakarta, Indonesia \\ Email: agus.uinjogja@gmail.com
}

\begin{abstract}
The environmental crisis, known as the ecological crisis, is becoming more widespread. It demands our care as human beings who assume the role of khalifah on earth to actively participate in preventing more massive environmental damage. Man can't live alone without the support of various resources that exist in his environment. However, the awareness of the importance of preserving and protecting the natural is still lacking. Environmental education is expected to be a vehicle to educate the general public and learners, in particular, to better understand the global environmental crisis phenomenon and foster an attitude to be more concerned with the environment, by internalizing religious values. Building an ecologically-based religious spirit should be conducted simultaneously and sustainably at all levels and compositions of the community especially Muslims, given that the ecological crisis has a universal impact. Recognizing the role of human as a caliph who is in charge of safeguarding and managing nature and the consequences of damaging the environment in terms of Islamic perspective is expected to arouse public awareness to participate actively in maintaining, managing wisely and preserving the surrounding environment.
\end{abstract}

Keywords: environmental ethics; environmental education; conservation; Islam.

\begin{abstract}
ABSTRAK
Krisis lingkungan atau yang dikenal sebagai krisis ekologi semakin hari semakin meluas. Hal ini menuntut kepedulian kita selaku manusia yang mengemban peran sebagai khalifah di bumi untuk berpartisipasi aktif dalam mencegah kerusakan lingkungan yang lebih massif. Manusia tidak dapat hidup sendiri tanpa dukungan dari berbagai sumber daya yang ada di lingkungannya. Namun, kesadaran akan pentingnya melestarikan dan melindungi alam dinilai masih kurang. Pendidikan lingkungan hidup diharapkan dapat menjadi suatu wahana untuk mengedukasi masyarakat umumnya dan peserta didik pada khususnya untuk lebih memahami fenomena krisis lingkungan global dan menumbuhkan sikap untuk lebih peduli pada lingkungan, dengan menginternalisasikan nilai-nilai agama. Membangun semangat keagamaan berbasis ekologis harus dilakukan secara serentak dan berkelanjutan pada semua level dan komposisi masyarakat khususnya ummat Islam, mengingat bahwa krisis ekologi itu berdampak universal. Memahamkan kembali peran manusia sebagai khalifah yang bertugas menjaga dan mengelola alam serta konsekuensi dari merusak lingkungan ditinjau dari perspektif Islam diharapkan dapat menggugah kesadaran masyarakat untuk
\end{abstract}


berpartisipasi aktif dalam menjaga, mengelola secara bijaksana dan melestarikan lingkungan hidup di sekitarnya.

Keywords: etika lingkungan; pendidikan lingkungan; konservasi; Islam.

\section{PENDAHULUAN}

Lingkungan menyediakan berbagai sumber daya bagi manusia dan makhluk-makhluk hidup lain yang menempatinya. Tanah, air dan udara merupakan 3 komponen penting yang menunjang hidup dan kehidupan yang ada di permukaan bumi. Dalam Al Quran dinyatakan bahwa penciptaan langit dan bumi serta berbagai sumber daya alam seperti angin (udara), air, tumbuh-tumbuhan dan hewan merupakan rahmat dari Allah untuk manusia (QS Al. A'raf: 57), sebagai hikmah (QS. Shad: 27) dan tanda-tanda kebesaran Allah (QS. Al Baqarah: 164; QS. Al A'raf: 58).

Manusia sebagai makhluk hidup yang tertinggi kedudukannya, dalam hidupnya sangat tergantung pada makhluk lain dan sumber daya alam yang ada di sekitarnya. Dukungan teknologi yang berkembang pesat, disamping memberikan keuntungan berupa berbagai kemudahan bagi manusia juga telah meningkatkan arogansi dan eksplorasi manusia terhadap lingkungan. Dalam interaksinya dengan lingkungan, terdapat dua peran yang ditempati oleh manusia. Pertama, manusia dapat berperan sebagai pembina, pemelihara dan pelestari lingkungan. Manusia dapat melakukan berbagai aktivitas yang berrdampak positif terhadap lingkungan seperti mengelola sampah, menanam pohon, mengurangi emisi karbon dioksida, mengurangi pemakaian plastik, dan lain-lain. Di sisi lain, aktivitas manusia menjadikannya dapat berperan sebagai perusak, pencemar, atau pengotor lingkungan yang dapat berimbas kepada ketidakseimbangan pada sistem alam sehingga menimbulkan berbagai permasalahan lingkungan (Ismarti, Ramses, Amelia, \& Suheryanto Suheryanto, 2017).

Krisis lingkungan telah menjadi isu global di abad ini. Berbagai masalah lingkungan seperti pemanasan global, penipisan ozon, krisis air, krisis energi dan kerusakan lingkungan akibat ulah manusia sudah sedemikian massiv. Pencemaran lingkungan tidak hanya terjadi di darat, namun juga di laut dan udara. Beberapa fakta tentang tingginya tingkat kerusakan lingkungan di Indonesia di antaranya adalah hilangnya 21\% dari 133 juta hektar hutan Indonesia karena tingginya laju deforestasi yang mencapai 1,8 juta hektar/tahun, rusaknya 30\% dari 2,5 juta hektar terumbu karang di Indonesia, tingginya tingkat pencemaran udara, pencemaran air, 
pencemaran tanah, dan pencemaran laut (Ismarti et al, 2017). Harian Kompas 11 September 2017 menyatakan bahwa kondisi pesisir laut Indonesia saat ini sangat kritis akibat cemaran plastik dan logam berat yang terjadi dalam dekade terakhir.

Bercermin pada banyaknya bencana dan kerusakan yang terjadi pada dekade ini, manusia modern perlu meninjau ulang pola interaksinya dengan alam. Adanya ancaman akan datangnya bahaya dan bencana yang sewaktu-waktu bisa "meluluhlantahkan" perdaban manusia akan sangat sulit dibendung oleh keserakahan manusia. Hal itu terjadi akibat eksploitasi alam yang melampaui batas, penggunaan teknologi yang tidak ramah lingkungan, ditambah lagi dengan faktor alam itu sendiri (Syamsudin, 2017).

Secara umum, penyebab kerusakan lingkungan hidup secara umum bisa dikategorikan dalam dua faktor penyebab yaitu peristiwa alam dan aktivitas manusia. Namun, kerusakan lingkungan akibat aktivitas manusia justru lebih besar dibanding kerusakan akibat bencana alam. Ini mengingat kerusakan yang dilakukan bisa terjadi secara terus menerus dan cenderung meningkat (Ismarti et al., 2017). Menurut (Aziz, 2014) pangkal tolak bencana dan kerusakan ini adalah kurangnya kearifan (moral) manusia dalam memperlakukan alam. Allah swt telah menegaskan bahwa manusia adalah penyebab terjadinya kerusakan alam. Hal ini dinyatakan dalam QS Ar Ruum ayat 41:

"Telah tampak kerusakan di darat dan di laut disebabkan perbuatan manusia, supaya Allah merasakan kepada mereka sebagian dari akibat perbuatan mereka agar mereka kembali (ke jalan yang benar)."

Saat ini, etika lingkungan yang dipegang masyarakat tradisional tergusur oleh pola kehidupan modern yang cenderung eksploitatif untuk memperoleh keuntungan sebanyakbanyaknya. Semua pihak masih terpaku pada kepentingan ekonomi yang sifatnya jangka pendek dengan terus menguras sumber daya alam, tanpa melihat sisi keselamatan manusia itu sendiri dan lingkungan. (Juwita, 2017). Penelitian (Azhar, Basyir, \& Alfitri, 2015) menganalisis hubungan pengetahuan lingkungan dan etika lingkungan terhadap sikap dan perilaku menjaga kelestarian lingkungan pada sekolah menengah (SMA, SMK dan MA) di Kota Pagar alam melaporkan bahwa pengetahuan lingkungan hidup memiliki hubungan positif yang cukup signifikan dengan sikap menjaga kelestarian lingkungan, namun pengetahuan etika lingkungan memiliki hubungan positif yang kurang signifikan dengan sikap menjaga kelestarian lingkungan. Pengetahuan lingkungan hidup dan etika lingkungan secara bersama-sama memiliki hubungan positif yang 
signifikan dengan sikap menjaga kelestarian lingkungan. Sedangkan sikap menjaga kelestarian lingkungan memiliki hubungan positif yang cukup signifikan dengan perilaku menjaga kelestarian lingkungan.

Umat Islam merupakan salah satu komunitas besar yang mendiami penjuru bumi. Dengan misi rahmatan lil 'aalamiin, seharusnya keberadaan umat Islam mempunyai pengaruh yang cukup signifikan dalam pemeliharaan dan penyelamatan lingkungan. Namun, menurut (Syamsudin, 2017), pemahaman teologi Islam (secara khusus tentang lingkungan) belum bisa ditangkap seluruhnya oleh umat Islam itu sendiri dan menjadi kesadaran bersama seluruh umat (tidak hanya umat Islam) untuk mewujudkan kelestarian alam dan lingkungan. Tulisan ini berusaha untuk memaparkan tentang tujuan dan implementasi PLH di sekolah serta etika dan konservasi lingkungan dalam prespektif Islam.

\section{PEMBAHASAN}

\section{Tujuan Pendidikan Lingkungan Hidup (PLH)}

Pendidikan merupakan wahana yang paling tepat untuk internalisasi dan transformasi keyakinan, nilai, pengetahuan dan keterampilan (Azhar et al., 2015). Pendidikan juga merupakan salah satu aspek penting dalam kehidupan yang menjadi salah satu sorotan penting dalam membangun gaya hidup dan sikap terhadap lingkungan. Oleh karena itu jalur pendidikan merupakan sarana yang tepat untuk membangun masyarakat yang menerapkan prinsip keberlanjutan dan etika lingkungan. Menurut (Djoehaeni, 2014) Pendidikan Lingkungan Hidup (PLH) diartikan sebagai upaya mengubah perilaku dan sikap yang dilakukan oleh berbagai pihak atau elemen masyarakat yang bertujuan untuk meningkatkan pengetahuan, keterampilan dan kesadaran masyarakat tentang nilai-nilai lingkungan dan isu permasalahan lingkungan yang pada akhirnya dapat menggerakkan masyarakat untuk berperan aktif dalam upaya pelestarian dan keselamatan lingkungan untuk kepentingan generasi sekarang dan yang akan datang.

Menurut (Afandi, 2013) tujuan PLH dapat dijabarkan menjadi lima kelompok, yaitu: (1) Kesadaran (awareness) yaitu membantu anak didik mendapatkan kesadaran dan peka terhadap lingkungan hidup dan permasalahannya secara menyeluruh (2) Pengetahuan (knowledge) yaitu membantu anak didik memperoleh dasar-dasar pemahaman tentang fungsi lingkungan hidup, interaksi manusia dengan lingkungannya (3) Sikap (attitudes) yaitu 
membantu anak didik mendapatkan seperangkat nilai-nilai dan perasaan tanggung jawab terhadap lingkungan alam, serta motivasi dan komitmen untuk berpartisipasi dalam mempertahankan dan mengembangkan lingkungan hidup (4) Keterampilan (skills) yaitu membantu anak didik mendapatkan keterampilan mengidentifikasi, investigasi dan kontribusi terhadap pemecahan dan penanggulangan isu-isu dan masalah lingkungan (5) Partisipasi (participation) yaitu membantu anak didik mendapatkan pengalaman, serta menggunakan pengetahuan dan keterampilan berpikirnya, untuk memecahkan dan menanggulangi isu-isu dan masalah lingkungan.

Islam sebagai agama samawi mempunyai misi rahmatan lil alamin. Oleh karena itu, peran Islam dalam penyelamatan lingkungan sekaligus penyelamatan peradaban manusia seluruhnya, tergantung dari kesadaran pemeluknya mengambil intisari ajaran-ajaran Islam (Syamsudin, 2017). Sebagai agama yang bersumber dari wahyu, terdapat beberapa petunjuk penting tentang berbagai peristiwa alam termasuk dalam hal ini adalah bencana alam dan masalah lingkungan dalam Al Quran. Menurut (Masruri, 2014) petunjuk tentang pemeliharaan lingkungan telah tertuang dalam tiga konsep dasar islam, yakni aqidah, syari'ah dan akhlak.

Pendidikan lingkungan sendiri telah diajarkan oleh Rasulullah berdasarkan wahyu, sehingga banyak ditemukan ayat-ayat al Quran yang berbicara tentang lingkungan. Karena Al-Quran hanya meletakkan dasar dan prinsipnya secara global, maka As-Sunnah menerangkan dan menjelaskan dalam bentuk hukum - hukum, pengarahan pada hal - hal tertentu dan berbagai penjelasan yang lebih rinci. Pendidikan lingkungan hidup dalam perspektif Islam didasari oleh prinsip-prinsip bahwa alam adalah ciptaan Allah, manusia adalah khalifah Allah di bumi, dan manusia harus melestarikan dan dilarang merusak alam semesta (Efendy, Hafidhuddin, \& Tanjung, 2016).

Islam telah meletakkan lima dasar yang dalam bahasa al Ghazali kulliyatul khams dan orentasi syariah yang dalam bahasa Asysyatibi maqashid as syariah yakni hifdzul 'aql (pemeliharaan terhadap akal), hifdzunnafs (menjaga harmonisasi jiwa), hifdzuddin (menjaga semangat agama), hifdzulmaal (menjaga eksistensi harta/ekonomi), dan hifdzunnasl wal irdh (menjaga kemurnian keturunan dan harga diri). Kemudian oleh Yusuf Qordhawi ditambahkan satu point sehingga maqasidussyariah-nya Asysyatibi itu berubah menjadi 6 poin yaitu hifdzulbi'ah (konservasi lingkungan). Fiqh lingkungan selanjutnya dikembangkan 
untuk mengawal keasadaran berkeagamaan yang selanjutnya dapat diimplementasikan pada wilayah natural (Ridwan, n.d.).

\section{Implementasi Pendidikan Lingkungan Hidup (PLH) di Sekolah}

Pendidikan lingkungan hidup, dapat diimplementasikan di setiap jenjang satuan pelajaran, sejak tingkat TK hingga ke Perguruan Tinggi. Penelitian (Djoehaeni, 2014) yang dilakukan pada 20 TK di Kecamatan Sukasari Kota Bandung melaporkan bahwa PLH sudah dikenal bahkan diterapkan di sekolah-sekolah tersebut. Hanya saja, guru masih menghadapi kendala karena belum adanya model pembelajaran yang bisa dijadikan acuan.

Menurut (Istiadi, n.d.) PLH dapat diajarkan melalui berbagai cara seperti observasi, diskusi, kegiatan atau praktek lapangan, praktik laboratorium, laporan kerja praktik, seminar, debat, kerja proyek, magang dan kegiatan petualangan. (Kholis \& Karimah, 2017) menyatakan bahwa praktik pembelajaran berbasis lingkungan hidup di sekolah dapat diimplementasikan ke dalam dua model yaitu pendidikan lingkungan hidup sebagai mata pelajaran muatan lokal dan pembelajaran berbasis lingkungan hidup yang diintegrasikan dengan mata pelajaran-mata pelajaran lainnya.

Penelitian Djoehaeni (2014) melaporkan bahwa Pendidikan Lingkungan Hidup pada jenjang Pendidikan Anak Usia Dini di Kecamatan Sukasari Kota Bandung masih belum optimal. Namun, Penerapan model pembelajaran berbasis inkuiri kontekstual pada Pendidikan Lingkungan Hidup pada Pendidikan Anak Usia Dini dapat meningkatkan hasil belajar anak-anak, terutama pada ranah kompetensi pengetahuan, sikap dan keterampilan yang mengacu pada Kurikulum Muatan Lokal Pendidikan Lingkungan Hidup.

Pada jenjang lebih tinggi, PLH dapat diintegrasikan dengan mata pelajaran lainnya. Pendidikan lingkungan hidup dapat dilaksanakan dengan pendekatan interdisipliner, multidisipliner dan transdisipliner (Afandi, 2013). Afandi menyebutkan bahwa pembelajaran IPS dirasa sangat tepat dalam mengajarkan pendidikan lingkungan hidup kepada siswa dari sekolah dasar (SD) sampai sekolah menengah (SMP/MTs dan SMA/SMK/MA). Pembelajaran lingkungan hidup melalui pembelajaran IPS dapat di lakukan dengan mengkaji isu-isu permasalahan global.

Pada kurikulum tahun 2006 (KTSP) pendidikan lingkungan hidup selain terintegrasi ke mata pelajaran lain, juga diberikan peluang menjadi pelajaran tersendiri melalui mata 
pelajaran muatan lokal (mulok). Selain itu juga dikembangkan Sekolah Peduli dan Berbudaya Lingkungan yang juga dikenal sebagai program Adiwiyata. sampai 2011 yang ikut partisipasi dalam program Adiwiyata telah mencapai 1.351 sekolah dari 251.415 sekolah (SD, SMP, SMA, dan SMK) Se-Indonesia dan pada tahun 2013, sekolah yang mengikuti program Adiwiyata meningkat lagi menjadi 4.132 sekolah dari 33 propinsi (Azhar et al., 2015).

Sekolah memiliki peran penting dalam mentransfer pengetahuan kepada para peserta didik. Menurut (Kholis \& Karimah, 2017) setidaknya terdapat tiga hal yang dapat dilakukan oleh sekolah agar peserta didik memiliki peran penting dalam menjaga dan memakmurkan alam sekitarnya. Pertama, sekolah hendaknya dapat mengajarkan teori-teori yang digali dari sumber dari segala sumber ilmu pengetahuan, Alquran dan al-Hadis. Kedua, sekolah dapat mengajarkan dan memberi tauladan bagaimana individu manusia melakukan interaksi dengan alam sekitarnya. Ketiga, sekolah dapat menanamkan kebiasaan dalam bersikap dan memperlakukan alam sekitarnya sehingga menghasilkan perilaku sosial yang baik.

Dalam implementasi PLH di sekolah, hal yang perlu diingat adalah bahwa dalam pembelajaran siswa harus dilibatkan secara aktif mentalnya, tidak hanya mendengarkan konsep secara pasif. Hal ini bertujuan agar siswa dapat mengonstruksi pengetahuan, pengalaman, dan keterampilannya yang pada gilirannya akan dapat diterapkan dalam kehidupannya dan ditransfer kepada orang lain. Penelitian (Kholis \& Karimah, 2017) di MIN Tegalasri, Wingi, Blitar, melaporkan bahwa strategi pembelajaran yang menggabungkan antara teori dengan praktik berdampak pada perubahan cara berfikir, bersikap dan berperilaku semua unsur sekolah, baik internal (pimpinan sekolah, dewan guru, murid, dan penjaga sekolah) maupun eksternal (komite sekolah, paguyuban kelas, dan dunia usaha yang terkait).

\section{Etika dan Konservasi Lingkungan dalam Islam}

\section{a. Etika Lingkungan menurut Islam}

Dalam pandangan Islam, manusia dan lingkungan memiliki hubungan atau relasi yang sangat erat. Konsep ekologi telah dikembangkan sebagai suatu disiplin ilmu yang mempelajari tentang makhluk hidup serta interaksi berbagai komponen di dalamnya. 
Pada hakekatnya, alam dan seluruh isinya mempunyai fungsi dan manfaat dalam kehidupan dunia ini seperti ditegaskan Allah dalam Surat Ar Rahman ayat 10:

"Dan Dia telah menghamparkan bumi untuk semua makhluk-Nya"

Maka Allah menciptakan makhluk hidup yang terdiri dari manusia, binatang, dan tumbuhan sebagai serangkaian ekologi dan membentuk suatu ekosistem yang saling mempengaruhi untuk keberlangsungan hidupnya. Konsep penciptaan alam semesta lainnya dijelaskan juga dalam QS. Ali Imran: 190-191, Luqman: 20, Al Qashash: 77, dan masih banyak lagi ayat lainnya.

Allah Swt menciptakan alam ini termasuk di dalamnya manusia dan lingkungan dalam keseimbangan dan keserasian sebagai suatu maha karya yang tanpa celah. Hal ini ditegaskan dalam QS Al Mulk ayat 3-4:

"Dialah (Allah) yang menciptakan tujuh langit berlapis-lapis. Tidak akan kamu lihat sesuatu yang tidak seimbang pada ciptaan Tuhan Yang Maha Pengasih. Maka lihatlah sekali lagi, adakah kaтu lihat sesuatu yang cacat? Kemudian ulangilah pandangan(ти) sekali lagi (dan) sekali lagi, niscaya pandanganmu akan kembali kepadamu tanpa menemukan cacat dan ia (pandanganmu) dalam keadaan letih.

Selanjutnya dalam QS Ar Rahmaan:7 dikatakan:

"Dan langit telah ditinggikanNya dan Dia telah menciptakan keseimbangan."

Keseimbangan dan keserasian ini harus dijaga agar tidak mengalami kerusakan. Gangguan terhadap salah satu komponen lingkungan akan mengubah keseimbangan sehingga dapat mempengaruhi komponen lingkungan yang lain (Harahap, 2015).

Etika lingkungan mengandung konsekuensi komitmen manusia terhadap kelangsungan daya dukung lingkungan ini baik untuk generasi manusia sekarang maupun generasi yang akan datang. Lingkungan hidup bukan semata milik generasi saat ini, namun merupakan titipan generasi yang akan datang. (Syamsudin, 2017). Dalam sejarah perkembangan pemikiran di bidang etika lingkungan, terdapat beberapa teori etika lingkungan yang dapat mempengaruhi pola perilaku manusia dalam berinteraksi dengan alam. Adapun teori tersebut adalah (Aziz, 2014):

1) Teori antroposentrisme, memandang manusia sebagai pusat dari sistem alam semesta. Manusia dan kepentingannya dianggap yang paling menentukan dalam tatanan ekosistem dan dalam kebijakan yang diambil dalam kaitan dengan alam, baik 
secara langsung maupun secara tidak langsung. Nilai tertinggi adalah manusia dan kepentingannya, dimana nilai dan prinsip moral hanya berlaku bagi manusia demikian juga etika. Namun, teori ini dianggap sebagai salah satu penyebab, bahkan penyebab utama, dari krisis lingkungan yang terjadi. Teori ini menyebabkan manusia mengeksploitasi dan menguras alam semesta demi memenuhi kepentingan dan kebutuhan hidupnya dan tidak peduli terhadap alam.

2) Teori biosentrisme, memandang setiap kehidupan dan makhluk hidup mempunyai nilai dan berharga pada dirinya sendiri. Tidak hanya manusia yang mempunyai nilai, alam juga mempunyai nilai pada dirinya sendiri lepas dari kepentingan manusia. Sebagai konsekuensinya, alam semesta adalah sebuah komunitas moral, baik pada manusia maupun pada makhluk hidup lainnya. Manusia maupun bukan manusia sama-sama memiliki nilai moral, dan kehidupan makhluk hidup apapun pantas dipertimbangkan secara serius dalam setiap keputusan dan tindakan moral, bahkan lepas dari perhitungan untung-rugi bagi kepentingan manusia.

3) Teori ekosentrisme, memandang makhluk hidup (biotik) dan makhluk tak hidup (abiotik) lainnya saling terkait satu sama lain. Etika diperluas untuk mencakup komunitas ekologis seluruhnya, baik yang hidup maupun tidak. Kewajiban dan tanggung jawab moral tidak hanya dibatasi pada makhluk hidup. Contohnya adalah deep ecology yang memusatkan perhatian pada makhluk hidup seluruhnya dalam kaitannya dengan upaya mengatasi persoalan lingkungan hidup.

4) Eko-feminisme adalah sebuah teori dan gerakan etika yang, sebagaimana halnya biosentris dan ekosentris, ingin mendobrak etika antroposentrisme yang lebih mengutamakan manusia dari pada alam. Bahkan secara lebih khusus, yang dilawan Eko-feminisme bukan hanya sekedar antroposentris, akan tetapi teori lingkungan yang berpusat pada laki-laki yang selama ini mempunyai cara pandang dominasi dan subordinasi, hirarkis yang menempatkan status bertingkat dan dualisme nilai untuk memberikan nilai tinggi dan rendah.

Pandangan Islam terhadap etika (khususnya) dalam kaitannya terhadap lingkungan hidup tercermin dari banyaknya ayat-ayat Allah SWT yang mengajarkan tentang konsep keseimbangan antara kehidupan dunia dan akhirat, karena dunia adalah 
sarana menuju kehidupan di akhirat (Syamsudin, 2017). Terdapat tiga tahapan dalam beragama yang dapat menjadi sebuah landasan etika lingkungan dalam perspektif Islam. Pertama ta`abbud yaitu bahwa menjaga lingkungan adalah merupakan impelementasi kepatuhan kepada Allah. Kedua, ta`aqquli. Perintah menjaga lingkungan secara logika dan akal pikiran memiliki tujuan yang sangat dapat difahami. Lingkungan adalah tempat tinggal dan tempat hidup makhluk hidup. Apabila ada ketidakseimbangan atau kerusakan yang dilakukan manusia, maka akan menimbulkan bencana yang bukan hanya akan menimpa manusia itu sendiri tetapi semua makhluk yang tinggal dan hidup di tempat tersebut akan binasa. Ketiga, takhalluq. Menjaga lingkungan harus menjadi akhlak, tabi`at dan kebiasaan setiap orang. Agar keseimbangan dan kelestarian alam terjadi dengan sendirinya tanpa harus ada ancaman hukuman dan sebab-sebab lain dengan iming- iming tertentu (Harahap, 2015).

\section{b. Konservasi lingkungan dalam pandangan Islam}

Menurut (Juwita, 2017), upaya untuk mengatasi krisis lingkungan hidup yang kini sedang melanda dunia bukanlah melulu persoalan teknis, ekonomis, politik, dan socialbudaya semata, melainkan diperlukan upaya penyelesaian dari berbagai perspektif, termasuk salah satunya adalah perspektif fiqh. Fiqih lingkungan adalah ketentuanketentuan Islam yang bersumber dari dalil - dalil yang terperinci tentang perilaku manusia terhadap lingkungan hidupnya dalam rangka mewujudkan kemaslahatan dan menjauhkan kerusakan.

Sukarni dalam bukunya Fiqih Lingkungan Hidup mengemukakan 3 konsep dasar fiqih lingkungan yaitu (Juwita, 2017):

1) Konsep ri'ayah al-bi'ah sebagai konsep integral ajaran Islam.

Konsep ini bila dibawa kedalam fiqh akan bermakna bahwa setiap perilaku yang bertujuan untuk menjaga dan memperbaiki lingkungan hidup menjadi bagian dari kewajiban yang harus dilaksanakan menurut ajaran agama Islam. Sebaliknya setiap tindakan destruktif terhadap lingkungan hidup berarti penistaan terhadap ajaran agama Islam itu sendiri dan diharamkan secara fiqh.

2) Konsep kewajiban kolektif (fardhu kifayah) dalam menjaga dan memperbaiki lingkungan hidup. 
Sebagai implikasinya penanganan problem lingkungan hidup mengharuskan ijtihad dan mujahadah semua pihak, terutama ulama', pemerintah, dan masyarakat. Kewajiban-kewajiban ekologis meliputi semua komponen, mulai dari kewajiban menjaga keseimbangan ekosistem, kewajiban pemanfaatan sumberdaya alam dan lingkunga secara lestari. Keseimbangan ekosistem adalah kondisi dinamis suatu ekosistem yang didukung oleh fungsi ekologis yang masing-masing komponennya secara wajar berfungsi sehingga memiliki daya dukung lingkungan yang optimum. Keseimbangan ekosistem dalam arti luas meliputi segala gerak dinamika kehidupan, baik dalam dunia fisik maupun social.

Hubungan antara manusia dengan alam atau hubungan manusia dengan sesamanya bukan merupakan hubungan antara penakluk dan yang ditaklukkan atau antara tuan dengan hamba tetapi hubungan kebersamaan dalam ketundukan kepada Allah Swt. Hal ini disebabkan kemampuan manusia dalam mengelola alam bukanlah akibat kekuatan yang dimilikinya tetapi akibat anugerah Allah Swt (Harahap, 2015). Allah telah menundukkan alam ini agar dapat dikelola dan dimanfaatkan oleh manusia. Hal ini secara eksplisit telah disebutkan dalam Surat Ibrahim ayat 32:

"Allah-lah yang telah menciptakan langit dan bumi dan menurunkan air (hujan) dari langit, kemudian dengan (air hujan) itu Dia mengeluarkan berbagai buah-buahan sebagai rezeki untukmu; dan Dia telah menundukkan kapal bagimu agar berlayar di lautan dengan kehendak-Nya, dan Dia telah menundukkan sungaisungai bagimu."

Selanjutnya dalam Surat Az Zukhruf ayat 13 dinyatakan:

"Agar kamu duduk di atas punggungnya kemudian kamu ingat nikmat Tuhanтu apabila kamu telah duduk di atasnya; dan agar kamu mengucapkan, "Maha-suci (Allah) yang telah menundukkan semua ini bagi kami padahal kami sebelumnya tidak mampu menguasainya."

Agama memang memberi penekanan pada etika dan rasa tanggung jawab terhadap alam. Oleh karena itu agama menawarkan kepada manusia agar memberi perhatian terhadap alam dan lingkungan dengan komitmen bahwa alam memiliki dan berada dalam satu tatanan nilai (Maliki, 2011). Beberapa ayat dalam Al Quran menegaskan untuk tidak melakukan kerusakan terhadap alam dan lingkungan, diantaranya QS. Al Qoshos:77; Ar Rahmaan: 8, As Syu'ara: 83, Al A'raf: 56 dan Al Ankabut:36. Di sisi lain, Surah Al Baqarah ayat 30 memberikan kewajiban manusia 
untuk menjaga lingkungan yang juga sangat terkait dengan posisi manusia sebagai khalifah (wakil Allah) di muka bumi. Maka manusia memiliki tanggung jawab untuk mengelola bumi dengan sebaik-baiknya sebagai sebuah amanah yang diberikan Allah SWT (Harahap, 2015). Menurut Syamsudin (2017), sebagai konsekuensi dari seorang khalifah Allah, manusia harus aktif di dunia, memelihara keharmonisan alam dan menyebarluaskan berkah dan karunia.

Dalam berbagai hadis, Nabi Muhammad SAW. memerintahkan umat Islam untuk tidak menebang pohon selama perang, dan menekankan konservasi lingkungan dan pencegahan kehancuran. Karena itu, melestarikan lingkungan adalah kewajiban agama bagi setiap Muslim. Dalam hadis, menanam pohon, dan menabur benih akan dipandang sebagai amal jariah, sebagai sunnah al-hasanah dengan ganjaran, baik di dunia berupa terjaganya keseimbangan alam, sumber pangan dan papan (untuk kasus lingkungan) serta balasan akhirat. Hadis yang diriwayatkan Ahmad dari Anas bin Malik, Nabi Muhammad SAW. Bersabda:

"Sekiranya kiamat datang, sedang di tanganmu ada anak pohon kurma, maka jika dapat (terjadi) untuk tidak berlangsung kiamat itu sehingga selesai menanam tanaman, maka hendaklah dikerjakan (pekerjaan menanam itu). Selanjutnya, "Barangsiapa di antara orang Islam yang menanam tanaman, maka hasil tanamannya yang dimakan akan menjadi sedekahnya, dan hasil tanaman yang dicuri akan menjadi sedekah. Barangsiapa yang merusak tanamannya, maka akan menjadi sedekahnya sampai hari Kiamat" (H.R. Muslim).

Mengenai binatang, Nabi bersabda:

"Dari Abu Hurairah, ia berkata bahwa Rasulullah SAW. Bersabda, "Orang yang menunggangi dan meminum (susunya) wajib memberinya makanan" (H.R. Bukhârî).

Menurut (Masruri, 2014) Rasulullah saw juga menekankan pentingnya konservasi melalui sabdanya yang diriwayatkan oleh Imam Muslim:

"Dari Jabir berkata, Nabi bersabda: sesungguhnya Ibrahim memaklumkan Mekkah sebagai sebagai tempat suci dan sekarang aku memaklumkan Madinah yang terletak diantara dua lava mengalir ( lembah) sebagai tempat suci. Pohon pohonnya tidak tidak boleh dipotong dan binatang - binatangnya tidak boleh diburu" ( HR. Muslim ).

Dengan demikian, melestarikan dan melindungi alam dengan usaha menanam dan menghijaukan tumbuh-tumbuhan merupakan perbuatan yang dapat 
mendatangkan pahala, dan orang-orang yang berbuat kerusakan di bumi diancam dengan ancaman neraka di akhirat kelak.

\section{KESIMPULAN}

Konsep pendidikan lingkungan hidup dalam Islam merupakan salah satu bukti, bahwa agama Islam merupakan agama yang sempurna. Sebagaimana firman Allah SWT:

... Pada hari ini telah Kusempurnakan untuk kamu agamamu, dan telah Ku-cukupkan kepadamu nikmat-Ku, dan telah Ku-ridai Islam itu jadi agama bagimu...(QS. Al Maidah:3)

Terwujudnya lingkungan yang baik tergantung pada pengamalan dari perintah Allah SWT:

Hai orang-orang yang beriman, masuklah kamu ke dalam Islam secara keseluruhannya, dan janganlah kamu turut langkah-langkah setan... (QS. Al Baqarah: 208)

Sebagai agama yang menekankan integritas iman, ilmu, dan amal. Setiap muslim di wajibkan peduli lingkungan. Hal-hal yang menjadi pola kerusakan lingkungan, sebagaimana yang telah Allah SWT gambarkan dalam surat Ar Ruum ayat 41:

"Telah tampak kerusakan di darat dan di laut disebabkan perbuatan manusia, supaya Allah merasakan kepada mereka sebagian dari akibat perbuatan mereka agar mereka kembali (ke jalan yang benar)."

Menjadi gambaran, bahwa siapaun yang tidak beriman kepada ayat-ayatNya cenderung memiliki karakter buruk terhadap lingkungan sekitar. Seperti ditekankan Nabi Muhammad SAW:

"Kebersihan itu adalah sebagaian dari iman".

Betapa keimanan yang baik akan memberikan dorongan karakter yang baik, sedangkan hilangnya sebagian iman akan mendistorsi perilaku-perilaku baik dalam diri seseorang.

\section{DAFTAR PUSTAKA}

Afandi, R. (2013). Integrasi Pendidikan Lingkungan Hidup melalui Pembelajaran IPS di Sekolah Dasar sebagai Alternatif Menciptakan Sekolah Hijau. Pedagogia, 2(1), 98-108. Retrieved from http://ojs.umsida.ac.id/index.php/pedagogia/article/viewFile/50/56

Azhar, A., Basyir, M. D., \& Alfitri, A. (2015). Hubungan Pengetahuan dan Etika Lingkungan dengan Sikap dan Perilaku Menjaga Kelestarian Lingkungan. Jurnal Ilmu Lingkungan, 
13(1), 36-41. https://doi.org/http://dx.doi.org/10.14710/jil.13.1.36-41

Aziz, A. (2014). Konservasi Alam dalam Perspektif Etika Islam: Tantangan dan Tuntutan Globalisasi. Akademika, 19(2), 307-321.

Djoehaeni, H. (2014). Model Pembelajaran Pendidikan Lingkungan Hidup Pada Anak Usia Dini. Edutech, 1(1), 1-20. Retrieved from http://jurnal.upi.edu/edutech/view/2876/modelpembelajaran-pendidikan-lingkungan-hiduppada-pendidikan-anak-usia-dini.html

Efendy, I., Hafidhuddin, D., \& Tanjung, H. (2016). Konstruksi Pendidikan Kesehatan Lingkungan dalam Perspektif Islam. Miqot, 40(2), 328-348.

Harahap, R. Z. (2015). Etika Islam dalam Mengelola Lingkungan Hidup. Jurnal EduTech Vol, 1(1). Retrieved from http://jurnal.umsu.ac.id/index.php/edutech/article/view/271

Ismarti, I., Ramses, R., Amelia, F., \& Suheryanto Suheryanto. (2017). Pengetahuan LIngkungan dan Pencemaran. (I. Ismarti, Ed.) (1st ed.). Batam: UNRIKAPress.

Istiadi, Y. (n.d.). Pendidikan lingkungan hidup terlupakan dalam kurikulum.

Juwita, D. R. (2017). Fiqh Lingkungan Hidup dalam Perspektif Islam. El-Wasathiya: Jurnal Studi Agama, 5(1), 27-42. Retrieved from http://ejournal.kopertais4.or.id/mataraman/index.php/washatiya/article/view/3025

Kholis, N., \& Karimah, R. (2017). Aksi Budaya Teo-Ekologi melalui Integrasi Kurikulum Pendidikan Lingkungan Hidup. Al-Tahrir, 17(2), 451-470.

Maliki, Z. (2011). Agama dan Lingkungan Hidup, 14(1), 137-147.

Masruri, U. N. (2014). Pelestarian Lingkungan dalam Perspektif Sunnah. At-Taqaddum, 6(2), 411-428. Retrieved from http://journal.walisongo.ac.id/index.php/attaqaddum/issue/view/Volume 6\%2C Nomor 2\%2C November 2014

Ridwan, M. (n.d.). Fiqh Ekologi.

Syamsudin, M. (2017). Krisis Ekologi Global dalam Perspektif Islam. Sosiologi Reflektif, 11(2), 83-106. 